\title{
ANALISIS SPASIAL TERHADAP PERSEBARAN FASILITAS SEKUNDER PARIWISATA DI KOTA MEDAN
}

\author{
Immanuel Sihombing', Ali Nurman ${ }^{2}$ \\ 'Alumnus S1 Jurusan Pendidikan Geografi Fakultas Ilmu Sosial Universitas Negeri Medan \\ 2Jurusan Pendidikan Geografi Fakultas Ilmu Sosial Universitas Negeri Medan \\ J. Willem Iskandar Psr V Medan Estate Medan, 20211 Indonesia \\ Email: alinurman.hutabarat@gmail.com
}

\begin{abstract}
Abstrak:
Penelitian ini bertujuan untuk mengetahui : (1) Pola persebaran objek wisata di Kota Medan (2) Pola persebaran hotel berbinang, (3) Pola persebaran hotel melati (4) kesesuaian pola persebaran objek wisata dengan pola persebaran hotel berbintang dan (5) Kesesuaian pola persebaran objek wisata dengan pola persebaran hotel melati di Kota Medan. Penelitian ini dilaksanakan di Kota Medan tahun 2016. Populasi dalam penelitian ini adalah seluruh objek wisata (20 objek wisata), hotel berbintang (48 hotel) dan hotel melati (25 hotel). Mengingat data yang diperlukan adalah data persebaran maka populasi dijadikan sekaligus sebagai sampel. Teknik pengumpulan data yang digunakan yakni teknik studi dokumenter dan pengukuran, data dianalisis dengan teknik analisis deskriptif kualitatif. Hasil penelitian menunjukkan : (1) Pola persebaran objek wisata di Kota Medan tergolong mengelompok, terutama disebabkan objek wisata menarik bagi wisatawan dan bernilai untuk dikunjungi hal ini ditunjukkan nilai $T$ yang diperoleh adalah 0,15 sehingga menarik bagi wisatawan dan dapat melayani kebutuhan wisatawan di objek wisata, (2) Pola persebaran hotel berbintang termasuk mengelompok, ini disebabkan jarak hotel berbintang relatif dekat dengan objek wisata keadaan itu dibuktikan nilai T yang diperoleh yakni 0,18 menyebabkan dapat melayani kebutuhan wisatawan yang beranekaragam di hotel berbintang, (3) Pola persebaran hotel melati tergolong pola persebaran yang semakin mengelompok, kondisi ini ditunjukkan nilai $T$ yang diperoleh yakni 0,09 menyebabkan kebutuhan pengunjung dapat terlayani di hotel melati, (4) Pola persebaran objek wisata memiliki kesesuaian dengan pola persebaan hotel berbintang. Dengan adanya kesesuaian kedua pola ini dapat memberikan pelayanan kebutuhan wisatawan di objek wisata dan pelayanan wisatawan yang beranekaragam di hotel berbintang yang pada gilirannya mendukung perkembangan fasilitas sekunder pariwisata. (5) Pola persebaran objek wisata memiliki kesesuaian dengan pola persebaran hotel melati. Adanya kesesuaian kedua pola tersebut, dapat melayani kebutuhan wisatawan di objek wisata sekaligus di hotel melati yang pada akhirnya dapat mendukung perkembangan pariwisata khususnya perkembangan pelayanan fasilitas sekunder pariwisata di Kota Medan.
\end{abstract}

\section{Kata kunci : sebaran, spasial, fasilitas, pariwisata, hotel}

\section{PENDAHULUAN}

Spasial sebagai keruangan suatu objek atau kejadian yang mencakup lokasi, letak dan posisinya. Lokasi yang dimaksud adalah lokasi absolut atau sudah pasti ditentukan dengan sistem koordinat garis lintang dan bujur, sedangkan lokasi relatif mempunyai sifat dinamik atau dapat berubah-ubah karena objek lain. Demikian juga letak dan posisi suatu tempat atau daerah harus mengenal koordinat grid ( garis-garis sejajar dengan arah vertikal dan horizontal) dan koordinat geografis (garis lintang dan bujur). Semua lokasi itu berhubungan erat dengan jarak. Hal itu berkaitan dengan pola persebaran yang lokasinya mengelompok, merata dan tidak merata di suatu tempat atau daerah tertentu. (kementrian Riset dan Teknologi, 2013 dan Bintarto, 1991).

Keadaan tersebut tidak jauh berbeda dengan keadaan pariwisata di 
suatu daerah atau wilayah tertentu memiliki lokasi yang bervariasi di antaranya lokasi objek wisata berbeda dengan lokasi fasilitas sekunder pariwisata. Demikian juga pola persebarannya ada kalanya sama dan adakalanya berbeda akan tetapi saling mendukung antara satu dengan yang lainnya sehingga menjadi daya tarik bagi pengunjung atau wisatawan. Oleh karena itu tidak jarang lokasi objek wisata dan lokasi fasilitas sekunder pariwisata kurang dikelola dengan baik, akibatnya jumlah pengunjung menjadi menurun. Sehubungan dengan itu bahwa lokasi objek wisata harus memiliki pemandangan yang indah atau menarik dan tersedianya fasilitas sekunder pariwisata. Fasilitas sekunder ini adalah (1) fasilitas akomodasi dengan berbagai jenis usaha yang menjual jasa mencakup hotel berbintang yang telah memiliki fasilitas lengkap dan hotel melati merupakan hotel dengan kualitas dan pelayanan yang minimum (2) fasilitas kuliner merupakan usaha menjual barang (rumah makan dan kedai) dan (3) fasilitas belanja seperti toko kerajinan dan souvenir (wenny, 2010).

Seiring dengan hal tersebut, kondisi kepariwisataan di Indonesia sangat menarik karena merupakan negara kepulauan yang kaya akan sumberdaya alam dan memiliki pemandangan alam yang indah berupa laut, pantai, danau, pegunungan, air terjun, hutan tropis dan banyak lagi pesona alam lainnya. Tak kalah pentingnya bahwa Indonesia terdiri dari bermacam suku bangsa dengan adat istiadat yang berbeda dan kaya akan peninggalan-peninggalan bersejarah berupa prasasti, candi, benda-benda kuno dan peninggalan lainnya yang memiliki nilai tinggi yang dapat disuguhkan kepada wisatawan domestik dan mancanegara. Seluruhnya merupakan objek wisata dan modal bagi pengembangan kepariwisataan.

Sebagai skala prioritas dalam pengembangan objek wisata ada 10 daerah tujuan wisata di Indonesia meliputi Daerah Khusus Jakarta, Jawa Barat, Jawa Tengah,
Daerah Istimewa Yogyakarta, Jawa Timur, Bali, Sumatera Barat, Sulawesi Selatan, Sulawesi Utara dan Sumatera Utara (Pendit, 1994). Dalam usaha ini pemerintah telah banyak melakukan pengembangan namun hasilnya belum sesuai dengan yang diharapkan. Hal ini ditunjukan jumlah wisatawan yang datang ke Indonesia tahun 2003 berjumlah 4.467.021 orang, tahun 2004 meningkat hingga mencapai 5.321 .165 orang, tahun 2005 jumlahnya menurun menjadi 5.002.101 orang, tahun 2006 menurun lagi hingga berjumlah 4.871 .351 orang akan tetapi tahun 2007 meningkat menjadi 5.505.759 orang (http://en.wikipedia.org diakses 2009/09/26).

Sumatera utara memiliki objek wisata tergolong sangat menarik karena keadaan pemandangan alam yang indah berupa laut, pantai, danau, sungai, air terjun, pegunungan, museum, kolam renang dan sebagainya. Objek wisata itu tersebar diseluruh Kabupaten/kota di antaranya Kabupaten Tapanuli Tengah, Samosir, Simalungun, Karo, Deli Serdang dan Kota Medan. Secara khusus di Kota Medan, objek wisatanya juga termasuk menarik di antaranya : Museum Istana Maimun, Gereja Velangkani, Kebun Binatang, Danau Siombak dan Penangkaran Buaya. Dengan adanya objek wisata ini, pariwisata di Kota Medan sudah mengalami perkembangan. Hal ini pada tahun 2012 wisatawan berjumlah 214.742 orang, tahun 2013 meningkat menjadi 233.998 orang, tahun 2014 bertambah hingga jumlahnya mencapai 243.641 orang dan tahun 2015 meningkat lagi menjadi 248.181 orang (Dinas Kebudayaan dan Pariwisata, 2016).

Berkembangnya pariwisata di Kota Medan tidak terlepas dari ketersediaan 20 objek wisata, ketersediaan fasilitas sekunder pariwisata seperti fasilitas akomodasi yang terdiri dari 48 hotel berbintang dan 25 hotel melati termasuk fasilitas kuliner dan fasilitas belanja. Masing-masing objek tersebut tersebar di berbagai tempat dengan jarak yang 
bervariasi sehingga membentuk pola persebaran objek wisata, pola persebaran hotel berbintang, pola persebaran hotel melati, pola persebaran fasilitas kuliner dan pola persebaran fasilitas belanja. Selain itu termasuk kesesuaian pola persebaran objek wisata dengan pola persebaran hotel berbintang dan kesesuaian pola persebaran objek wisata dengan pola persebaran hotel melati. Semuanya telah memberikan pelayanan untuk memenuhi kebutuhan wisatawan, namun hasilnya belum optimal. Oleh karena itu perlu dilaksanakan analisis spasial terhadap persebaran fasilitas sekunder pariwisata di Kota Medan.

Tujuan yang hendak dicapai dalam penelitian ini, untuk mengetahui : (1) Pola persebaran objek wisata di Kota Medan; (2) Pola persebaran hotel berbintang di Kota Medan; (3) Pola persebaran hotel melati di Kota Medan; (4) Kesesuaian pola sebaran objek wisata dengan pola persebaran hotel berbintang di Kota Medan; (5) Kesesuaian pola persebaran objek wisata dengan pola persebaran hotel melati di Kota Medan.

\section{METODE PENELITIAN}

Penelitian ini berlokasi di Kota Medan. Alasan pemilihan lokasi ini adalah (1) belum optimalnya dalam melayani kebutuhan wisatawan, (2) ingin melihat secara langsung keberadaan lokasi objek wisata, lokasi hotel berbintang dan hotel melati, (3) belum pernah dilakukan penelitian yang sama di Kota Medan.

Populasi dalam penelitian adalah seluruh objek wisata yang terdapat di 20 lokasi, hotel berbintang terdapat di 48 lokasi dan seluruh hotel melati yang terdapat di 25 lokasi di Kota Medan. Sesuai dengan tujuan penelitian membutuhkan data pola persebaran dan jumlah populasi masih memenuhi syarat untuk sampel total, dengan demikian populasi adalah sebagai sampel.

Variabel dalam penelitian ini terdiri dari pola persebaran objek wisata, pola persebaran hotel berbintang, pola persebaran hotel melati, kesesuaian pola persebaran objek wisata dengan pola sebaran hotel berbintang, dan kesesuaian pola persebaran objek wisata dengan pola persebaran hotel melati.

Teknik pengumpulan data yang dipakai dalam penelitian ini, antara lain

1. Teknik studi dokumenter. Alat yang digunakan yakni daftar studi dokumentasi berisi tentang seluruh objek wisata, lokasi hotel berbintang dan seluruhhotel melati di Kota Medan. Data diperoleh dari kantor Dinas Kebudayaan dan Pariwisata tahun 2016.

2. Teknik pengukuran. Alat yang dipakai yakni GPS (Global Possition System) untuk mengukur lintang dan bujur setiap objek wisata, lintang dan bujur setiap lokasi hotel berbintang dan mengukur lintang dan bujur hotel melati di Kota Medan.

Teknik analisis data yang digunakan adalah teknik analisis deskriptif kualitatif yakni menganalisis data-data secara sistematik dibantu dengan tabel persentasi dan peta pola persebaran tentang objek wisata,hotel berbintang dan setiap hotel melati. Kemudian dilakukan analisis tetangga terdekat untuk mengetahui pola persebaran objek wisata, pola persebaran hotel berbintang, dan pola persebaran hotel melati sehingga dapat memberi gambaran tentang pola persebaran mengelompok, merata dan tidak merata serta kesesuaian antar pola akhirnya lebih mudah untuk dipahami dan disimpulkan. Rumus yang 
digunakan dalam menganalisis tetangga terdekat (Bintarto, 1991) :

$\mathrm{T}=\frac{J U}{J H}$

Keterangan :

$\mathrm{T}=$ Indeks penyebaran lokasi

$\mathrm{JU}=$ Jarak rata-rata yang diukur antara satu titik dengan titik lainnya $\mathrm{JH}=$ Jarak rata-rata yang diperoleh andaikan semuanya mempunyai random

$\mathrm{P} \quad=$ Kepadatan titik dalam setiap kilometer persegi yaitu jumlah titik $(N)$ dibagi dengan luas wilayah dalam kilometer persegi $(A)$ hingga menjadi $=$ $\frac{N}{A}$. untuk memperoleh ju digunakan cara dengan menjumlahkan semua jarak terdekat dan kemudian dibagi dengan jumlah titik yang ada $\mathrm{ju}=\frac{J}{N}$

Dalam mengetahui pola persebaran dapat dihitung berdasarkan persebaran terdekat (T) dan parameternya (nearest seightbour statistic) dapat digunakan dengan rangkaian kesatuan (continuum) untuk memperoleh perbandingan antar pola titik seperti berikut :

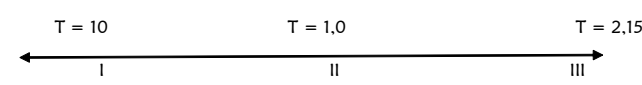

Keterangan :

$\mathrm{I}=<1$ berarti mengelompok (bergerombol)

$I=1,0-2,14$ berarti tidak merata (random)

$\mathrm{III}=\geq 2,15$ merata (seragam)
Selanjutnya untuk mengetahui persebaran mengelompok adalah semakin kecil nilai $T$ maka semakin mengelompok persebarannya dan semakin terlayani kebutuhan wisatawan, untuk persebaran merata yakni semakin besar nilai $T$ maka semakin merata persebarannya dan semakin terlayani kebutuhan wisatawan.

\section{HASIL DAN PEMBAHASAN \\ Pola Persebaran Objek Wisata di Kota Medan}

Pola persebaran ini adalah sebagai hasil dari seluruh persebaran objek wisata di Kota Medan.Objek wisata yang tersebar itu adalah objek wisata Museum Perjuangan di Jl.KH.Zainaul Arifin, Rumah Tjong A.Fie Jl. Putri Hijau, Pekan Raya Sumut Jl. Gatot Subroto, Gedung Balai Kota Jl. Balai Kota, Kuil Shri Mariamman Jl. Teuku Umar, Gereja Katederal Medan Jl. Pemuda, Gedung Lomsum Jl. Putri Hijau, Gedung Dharma Deli Jl. Balai Kota, Kantor Pos Jl. Balai Kota, Museum Negeri Medan Jl. Gedung Arca, Istana Maimun Jl. Brigjen Katamso, Mesjid Raya Medan Jl. Sisingamangaraja, Museum Satwa Rahmat Jl. S. Parman, Viahar Gunung Timur Jl. Hang Tuah, Menara Tirtanadi Jl. Martapura, Gereja Velangkani Jl. Sakura Tanjung Selamat, Kebun Binatang Jl. Simalingkar B, Situs Kota Cina Jl. Pasar Nipon Marelan, objek wisata Danau Siombak Jl. Marelan dan objek wisata Penangkaran Buaya di Jl. Sunggal tergolong pola persebaran mengelompok.

Tabel 10. Lokasi Objek Wisata Di Kota Medan Tahun 2016

\begin{tabular}{|c|c|c|c|c|}
\hline \multirow[t]{2}{*}{ No } & \multirow[t]{2}{*}{ Nama Objek Wisata } & \multirow[t]{2}{*}{ Alamat } & \multicolumn{2}{|c|}{ Koordinat } \\
\hline & & & LU & BT \\
\hline 1 & Istana Maimun & Jl. Brigjen Katamso & $3^{\circ} 34^{\prime} 31^{\prime \prime}$ & $98^{\circ} 41^{\prime} 02$ \\
\hline 2 & Mesjid Raya Medan & Jl. Sisingamangaraja & $3^{\circ} 34^{\prime} 31^{\prime \prime}$ & $98^{\circ} 41^{\prime} 14^{\prime \prime}$ \\
\hline 3 & Museum Perjuangan & Jl. K.H Zainul Arifin & $3^{\circ} 35^{\prime} 01^{\prime \prime}$ & $98^{\circ} 40^{\prime} 26^{\prime \prime}$ \\
\hline 4 & Kantor Pos & Jl. Balai Kota & $3^{\circ} 35^{\prime} 29^{\prime \prime}$ & $98^{\circ} 40^{\prime} 38^{\prime \prime}$ \\
\hline 5 & Rumah Tjong A Fie & Jl. Putri Hijau/Kesawan Square & $3^{\circ} 35^{\prime} 07^{\prime \prime}$ & $98^{\circ} 40^{\prime} 49^{\prime \prime}$ \\
\hline 6 & Pekan Raya Sumut & Jl. Gatot Subroto Km 5,6 & $3^{\circ} 35^{\prime} 29^{\prime \prime}$ & $98^{\circ} 37^{\prime} 47^{\prime \prime}$ \\
\hline 7 & Gereja Velangkani & Jl. Sakura Tanjung Selamat & $3^{\circ} 32 ’ 51^{\prime \prime}$ & $98^{\circ} 36^{\prime} 31^{\prime \prime}$ \\
\hline 8 & Gedung Balai Kota & Jl. Balai Kota & $3^{\circ} 35^{\prime} 25^{\prime \prime}$ & $98^{\circ} 40^{\prime} 38^{\prime \prime}$ \\
\hline
\end{tabular}




\begin{tabular}{|c|l|l|l|c|}
\hline No & \multicolumn{1}{|c|}{ Nama Objek Wisata } & \multicolumn{2}{|c|}{ Alamat } & \multicolumn{2}{|c|}{ Koordinat } \\
\cline { 3 - 4 } & & & LU & BT \\
\hline 9 & Kebun Binatang & Jl. Simalingkar B & $3^{\circ} 32^{\prime} 54^{\prime \prime}$ & $98^{\circ} 41^{\prime} 11^{\prime \prime}$ \\
10 & Museum Satwa Rahmat & Jl. S.Parman/ Jl. T.D Pardede & $3^{\circ} 34^{\prime} 45^{\prime \prime}$ & $98^{\circ} 40^{\prime} 02^{\prime \prime}$ \\
11 & Kuil Shri Mariamman & Jl. Teuku Umar & $3^{\circ} 35^{\prime} 01^{\prime \prime}$ & $98^{\circ} 40^{\prime} 15^{\prime \prime}$ \\
12 & Situs Kota Cina & Jl. Pasar Nipon Marelan & $3^{\circ} 43^{\prime} 23^{\prime \prime}$ & $98^{\circ} 39^{\prime} 22^{\prime \prime}$ \\
13 & Gereja Katedral Medan & Jl. Pemuda & $3^{\circ} 35^{\prime} 03^{\prime \prime}$ & $98^{\circ} 40^{\prime} 52^{\prime \prime}$ \\
14 & Gedung Lonsum & Jl. Putri Hijau & $3^{\circ} 35^{\prime} 19^{\prime \prime}$ & $98^{\circ} 40^{\prime} 41^{\prime \prime}$ \\
15 & Vihara Gunung Timur & Jl. Hang Tuah & $3^{\circ} 34^{\prime} 38^{\prime \prime}$ & $98^{\circ} 40^{\prime} 06^{\prime \prime}$ \\
16 & Gedung Dharma Deli & Jl. Balai Kota & $3^{\circ} 35^{\prime} 28^{\prime \prime}$ & $98^{\circ} 40^{\prime} 37^{\prime \prime}$ \\
17 & Menara Tirtanadi & Jl. Martapura & $3^{\circ} 34^{\prime} 57^{\prime \prime}$ & $98^{\circ} 41^{\prime} 06^{\prime \prime}$ \\
18 & Danau Siombak & Jl. Marelan & $3^{\circ} 43^{\prime} 29^{\prime \prime}$ & $98^{\circ} 39^{\prime} 32^{\prime \prime}$ \\
19 & Museum Negeri Medan & Jl. Gedung Arca & $3^{\circ} 34^{\prime} 06^{\prime \prime}$ & $98^{\circ} 41^{\prime} 45^{\prime \prime}$ \\
20 & Penangkaran Buaya & Jl. Sunggal & $3^{\circ} 33^{\prime} 59^{\prime \prime}$ & $98^{\circ} 37^{\prime} 07^{\prime \prime}$ \\
\hline
\end{tabular}

Sumber : Dinas Kebudayaan dan Pariwisata Kota Medan, 2016

Keadaan tersebut sesuai dengan yang dikemukakan Bintarto (1991) yakni bila nilai $T$ yang diperoleh lebih kecil dari satu $(=<1)$ berarti persebaran mengelompok (bergerombol). Bila dilihat dari efektifnya angka yang dihasilkan atau semakin kecil angka nilai $\mathrm{T}$ maka semakin mengelompok dan semakin efektif atau semakin terlayani kebutuhan wisatawan. Dalam kenyataannya angka untuk pola persebaran objek wisata berada di urutan kedua $(T=0,15)$. Walaupun demikian tidak begitu berpengaruh terhadap objek wisata karena objek wisata tersebut sudah menarik dan bernilai untuk dikunjungi.Hanya saja tidak dapat berkembang jika tak didukung faktor lainnya. Ternyata lokasinya strategis karena dekat dengan permukiman penduduk, tidak begitu jauh dari pusat Kota Medan (kantor pos) dan didukung dengan adanya ketersedian prasarana jalan aspal sepanjang 3.162, $61 \mathrm{~km}$ dalam kondisi baik dan $177,49 \mathrm{~km}$ dalam kondisi sedang, demikian juga sarana angkutan umum, angkutan kereta api, angkutan udara di bandara Polonia dan Pelabuhan Belawan cukup tersedia. 


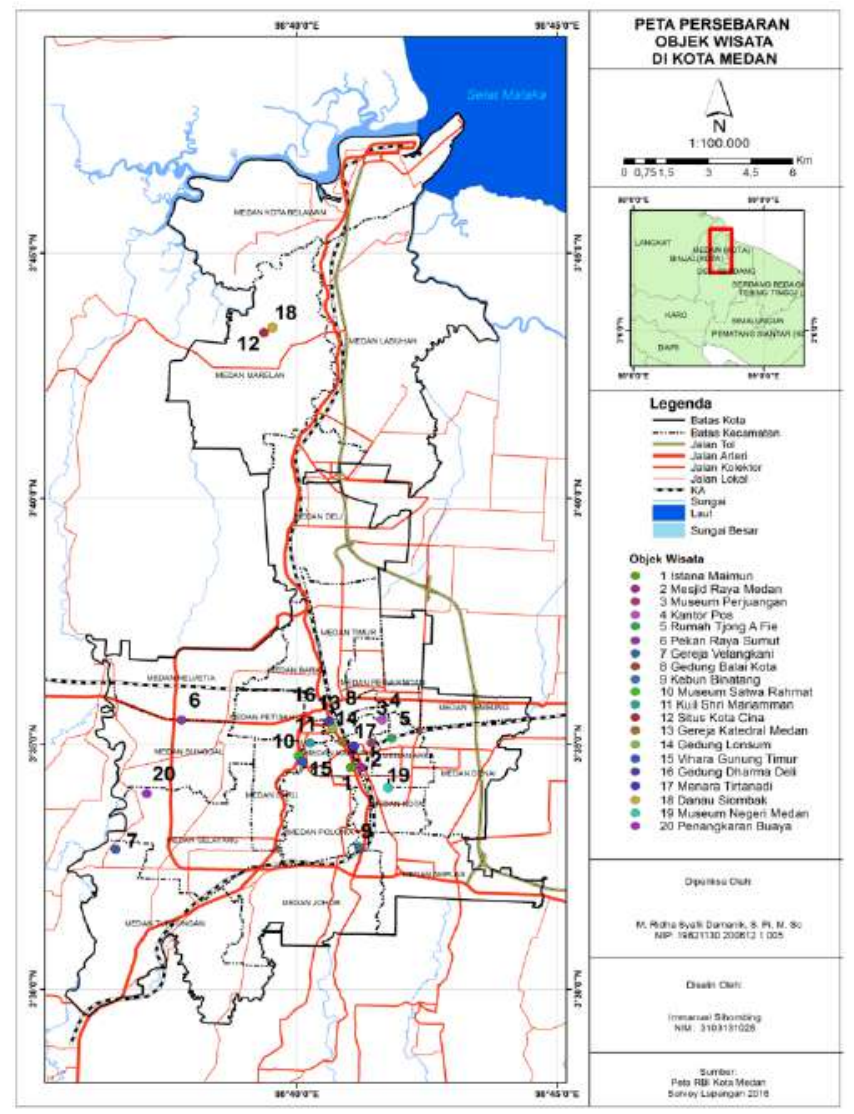

Gambar 1. Peta Pola Persebaran Objek Wisata Kota Medan

Kondisi tersebut menyebabkan semakin menarik bagi wisatawan dan dapat melayani kebutuhan wisatawan yang pada akhirnya dapat mendukung perkembangan pariwisata khususnya perkembangan fasilitas sekunder pariwisata, ini ditunjukan jumlah wisatawan sebesar 243.641 orang pada tahun 2014 meningkat menjadi 248.181 orang pada tahun 2015 di Kota Medan. Hal tersebut seirama dengan yang dikatakan Setiawan (2003) yakni lokasi merupakan faktor yang sangat menentukan bagi berkembangnya pusat-pusat pertumbuhan daerah.Daerah-daerah yang lokasinya sangat strategis memiliki kemungkinan berkembangnya secara lebih cepat dibandingkan dengan daerah-daerah di sekitarnya.Agar suatu daerah berkembang dengan pesat faktor sumberdaya alam hendaknya didukung dengan kemudahan prasarana dan sarana transportasi yang dalam hal ini berlaku juga bagi pariwisata di Kota Medan.

\section{Pola Persebaran Hotel Berbintang di Kota Medan}

Pola persebaran fasilitas hotel ini merupakan hasil dari seluruh persebaran hotel berbintang di Kota Medan. Adapun hotel yang tersebar adalah Hotel Grand Impression di Jl. Setia Budi, Pardede Internasional Jl. Juanda, Grand Delta Jl. Juanda, Madani Jl. Amaliun, Grand Sri Intan Jl. Sisingamangaraja, Dhaksina JI. Sisingamangaraja, Garuda Citra Jl. Sisingamangaraja, Sumatera Jl. Sisingamangaraja, Medan Ville Jl. Komp. Multatuli, Candi JI. Darussalam, Garuda Plaza Jl. Sisingamangaraja, Polonia Jl. Polonia, Tiara Jl. Cut Mutia, Danau Toba Jl. Imam Bonjol, Soechi Jl. Cirebon, Hermes Internasional Jl. Pemuda, Grand Sirao Jl. Semarang, Lebana Inn Jl. Abdulah Lubis, Motel Danau Toba Jl. Hayam 
Wuruk dan lokasi fasilitas Swiss Bel-Inn di Jl. Surabaya.

Selanjutnya adalah hotel yang tersebar yakni hotel Wai Yat Jl. Asia, Swiss - Bel Cambridg JI. S.Parman, Gajah Mada Jl. Gajah Mada, Travellers Suites Jl. Listrik, Kenaya Jl. Darussalam, 61 Hotel Jl. Iskandar Muda, Putra Mulia Abadi Jl. Gatot Subroto, Inna Dharma Deli JI. Balai Kota, Serela Jl. Gatot Subroto, Santika JI. Kapt. Maulana Lubis, Grand Aston JI. Balai Kota, Arya Duta Regency Jl. Kapt Maulana Lubis, Grand Angkasa Jl. Sutomo, J.W. Marriot Jl. Putri Hijau, Asean Internasional Jl. H. Adam Malik, Syariah Granf Jamee Jl. Merpati, Elegant Jl. Waringin, Grand Sakura Jl. HM. Yamin, Royal Perintis Jl. Perintis Kemerdekaan, Hotel Sunggal $\mathrm{Jl}$. Pantai Barat, Pelangi Internasional Jl. Letjen Jamin Ginting dan Hotel Lonari di Jl. Letjen Jamin Ginting. Pola persebaran lainnya adalah pola persebaran tidak merata yang terdiri dari : Hotel Metro Medan di Jl. Sisingamangaraja, Antares JI. Sisingamangaraja, Emerald garden Jl. Putri Hijau dan hotel Cottege Danau Toba Jl. Gabion Ujung Baru.

Keadaan tersebut seirama dengan yang dikemukakan Bintarto (1991) yakni bila nilai $T$ yang diperoleh lebih kecil dari satu $(=<1)$ berarti persebaran mengelompok (bergerombol). Bila dilihat dari efektifnya angka yang diperoleh atau semakin kecil nilai $T$ maka semakin mengelompok dan semakin efektif atau semakin terlayani kebutuhan wisatawan. Hasil nilai $T$ yang diperoleh berada diurutan ketiga $(T=0,18)$. Walaupun berada di urutan terakhir tetapi yang menjadi ciri khasnya adalah jarak hotel terhadap objek wisata relatif dekat, diantaranya (1) Hotel Madani berjarak 416 meter ke objek istana maimun, hotel Grand Sri ke Istana Maimun dengan jarak 378 meter dan hotel Garuda Plaza ke Istana Maimun dengan jarak 401 meter, (2) Hotel Soechi berjarak 96 meter ke Menara Tirtanadi, Hotel Swiss inn ke Menara Tirtanadi dengan jarak 65 meter dan Hotel Grand Sirao ke Menara Tirtanadi dengan jarak 97 meter, (3) Hotel Antares berjarak 192 meter ke Mesjid Raya dengan jarak 222 meter dan Hotel Madani ke Mesjid Raya dengan jarak 131 meter.

Adanya jarak yang relatif dekat tersebut, maka wisatawan dapat pergi ke tempat objek wisata dan pulang ke hotel (penginapan) dengan jalan kaki dan dapat pula sholat di Mesjid Raya sehingga semua kebutuhan wisatawan yang beranekaragam dapat terpenuhi di hotel berbintang satu sampai hotel berbintang lima. Hal ini salah satu penyebab dapat mendukung meningkatnya jumlah pengunjung dan berkembangnya pariwisata terutama perkembangan pelayanan fasilitas sekunder pariwisata di Kota Medan.Keadaan ini tidak sesuai dengan yang dikemukakan Bintarto (1991) yakni semakin kecil nilai T maka semakin efektif atau semakin terlayani kebutuhan wisatawan. Ternyata dilapangan pola persebaran hotel berbintang yang mengelompok itu bukan memiliki angka yang efektif tetapi memliki nilai $T$ yang tertinggi, namun masih dapat melayani kebutuhan wisatawan dan ini terutama disebabkan jarak hotel dengan objek wisata relatif dekat seperti terjadi di Kota Medan. 


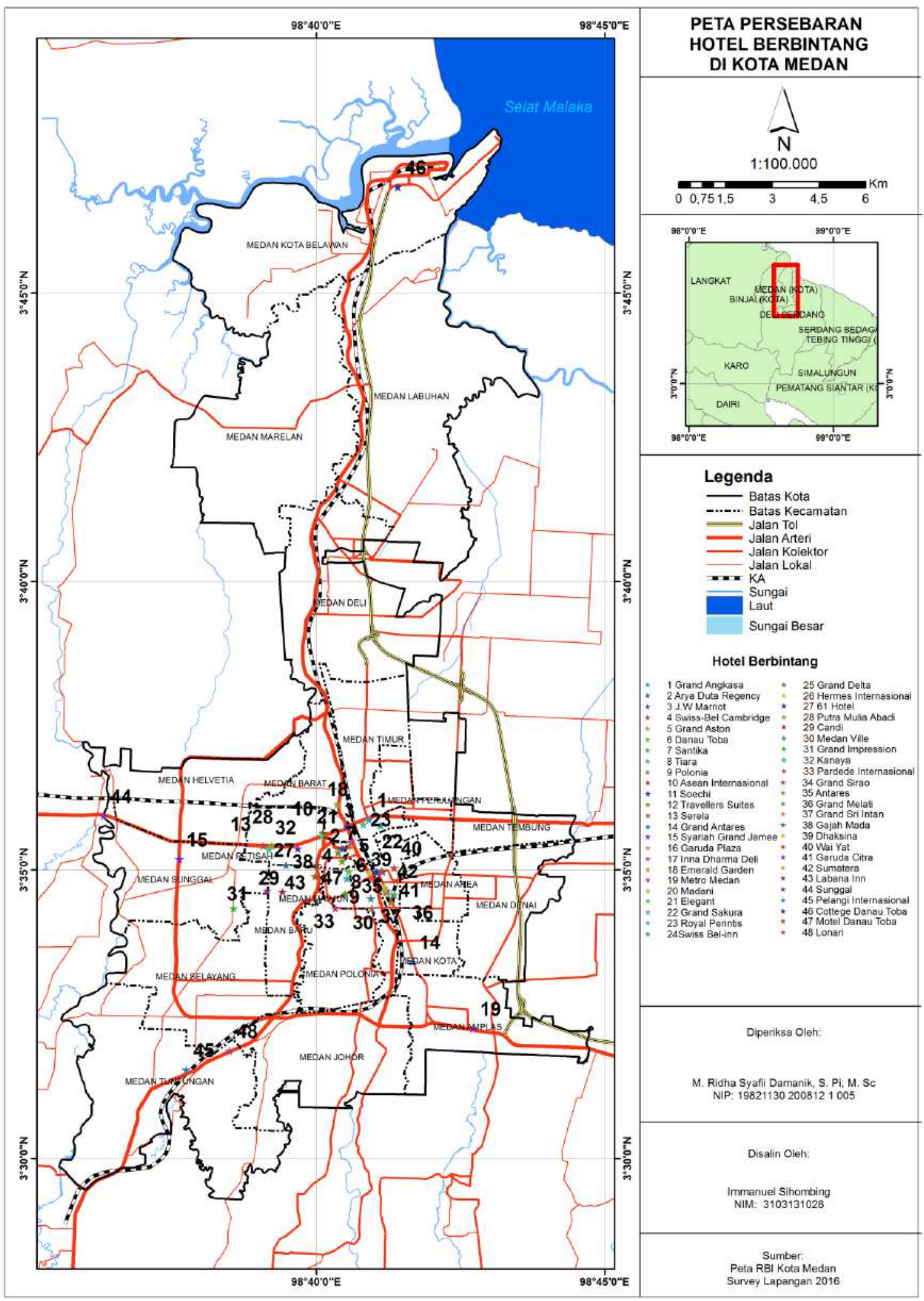

Gambar 2. Peta Pola Persebaran Hotel Berbintang di Kota Medan 


\section{Pola Persebaran Hotel Melati Di Kota Medan \\ Pola persebaran hotel melati} diperoleh dari seluruh persebaran hotel melati di Kota Medan. Hotel yang tersebar adalah Hotel Chery di JI. K.H. Wahid Hasyim, Islam Aceh House Jl. K.H. Wahid Hasyim, Rakashi Jl. K.H. Wahid Hasyim, Graha Buana JI. K.H. Wahid Hasyim, Al Jayri JI. K.H. Wahid Hasyim, Seulawah JI. Gatot Subroto, Merilyn Jl. Gatot Subroto, Menara Jl. Gatot Subroto, Novi Jl. Gatot Subroto, Limbo Jl. Gatot Subroto, Lee
Garden Jl. Nibung Baru, Super Jl. Nibung Baru, Patisah Jl. Nibung II, Bumi Malaya Jl. Gatot Subroto, Cirasa Jl. Gatot Subroto, Serene Anggrek Jl. Gatot Subroto, Transit Syariah Jl. Gajah Mada, Cordela Jl. Prof. H.M.Yamin, Istana Jl. Juanda Baru, Sukma City Jl. Sisingamangaraja, Zakia Jl. Sipisopiso, Amaliun Jl. Amaliun, Banda Agung Jl. Pinang Baris, Hotel Bumi Asih di Jl. Sei Bahorok Baru dan Hotel Bona Borta Jl. Tanjung Selamat tergolong persebaran mengelompok.

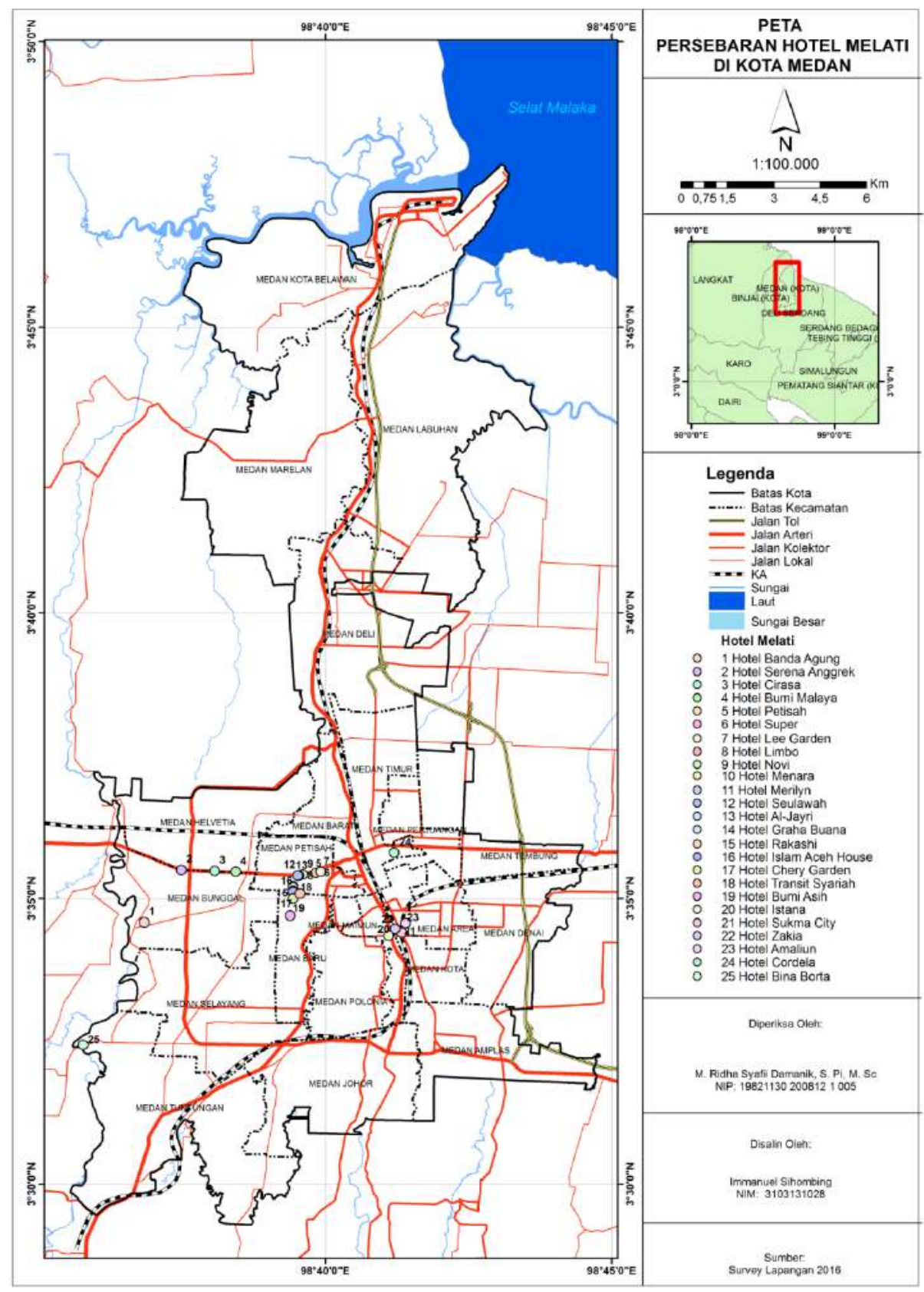


Gambar 3. Peta Persebaran Hotel Melati di Kota Medan

Keadaan tersebut sesuai dengan yang dikemukakan Bintarto (1991) yakni bila nilai $T$ yang diperoleh lebih kecil dari satu ( $=<1$ ) berarti mengelompok (bergerombol). Bila dilihat dari efektifnya angka yang dihasilkan atau semakin kecil nilai $\mathrm{T}$ maka semakin mengelompok dan semakin efektif atau semakin terlayani kebutuhan wisatawan. Hasil nilai yang diperoleh berada di urutan pertama ( $\mathrm{T}=$ 0,09 ) atau nilai $T$ yang dihasilkan semakin kecil sehingga pola persebaran hotel melati tergolong semakin mengelompok menyebabkan semakin terlayani kebutuhan wisatawan di hotel melati.Hal ini tidak terlepas dari lokasinya strategis karena dekat dengan pemukiman penduduk memudahkan pengunjung berbaur dengan penduduk setempat dan harga hotel per kamar jauh lebih murah dibandingkan dengan harga per kamar dihotel berbintang.

Kondisi yang demikian salah satu penyebab meningkatnya jumlah pengunjung yang pada akhirnya dapat mendukung perkembangan pariwisata khususnya perkembangan pelayanan fasilitas sekunder pariwisata di Kota Medan.Keadaan tersebut sesuai dengan yang dikemukakan Bintarto (1991) yakni semakin kecil nilai $T$ maka semakin mengelompok persebarannya dan semakin efektif atau semakin terlayani kebutuhan wisatawan, hal ini terjadi juga di Kota Medan.

\section{Kesesuaian Pola Persebaran objek Wisata Dengan Pola Persebaran Hotel Berbintang di Kota Medan}

Pola perebaran objek wisata di Kota Medan tergolong mengelompok, lokasinya strategis, adanya ketersediaan prasarana jalan dan sarana angkutan. Demikian juga pola persebaran hotel berbintang termasuk mengelompok, lokasi strategis,adanya ketersediaan prasarana dan sarana perhubungan. Melihat kondisi itu, pola persebaran objek wisata memiliki kesesuaian dengan pola persebaran hotel berbintang. Hal ini ditunjukan pola persebaran objek wisata sebagai tempat yang sentral yang memiliki daya tarik wisatawan yang paling utama, dapat melayani kebutuhan wisatawan dan mempengaruhi atau melayani wisatawan di hotel berbintang mulai dari berbintang satu hingga berbintang lima. Hal itu didukung kedua pola persebaran tersebut memiliki lokasi yang strategis dan ketersediaan prasarana jalan serta ketersediaan sarana angkutan menyebabkan jumlah wisatawan meningkat dan telah mengalami perkembangan dalam melayani kebutuhan wisatawan di hotel berbintang yang pada akhirnya dapat mendukung perkembangan pariwisata khususnya perkembangan pelayanan fasilitas sekunder pariwisata di Kota Medan.

Keadaan tersebut tidak jauh berbeda dengan yang dikemukakan Cristaller (dalam Setiawan, 2003) yakni cara yang baik untuk menyediakan pelayanan berdasarkan aspek keruangan kepada penduduk adalah dengan menerapkan aktivitas pada hirarki permukiman yang luasnya meningkat dan lokasinya ada pada simpul-simpul jaringan heksagonal. Oleh karena itu lokasi kegiatan yang melayani kebutuhan penduduk itu harus ada pada lokasi yang sentral. Sehingga situasi lalulintas yang optimum memiliki pengaruh setengah dari bagian tetangga disekitarnya yang berbentuk heksagonal selain mempengaruhi wilayah itu sendiri. Hal itu berlaku juga untuk pola persebaraan objek wisata dan pola persebaraan hotel berbintang di Kota Medan.

Kesesuaian Pola Persebaran Objek Wisata
Dengan Pola Persebaran Hotel Melati Di
Kota Medan
Pola persebaran objek wisata di Kota Medan termasuk mengelompok, lokasinya startegis, adanya ketersediaan 
prasarana jalan dan sarana angkutan.Sama halnya dengan pola persebaran hotel melati tergolong mengelompok, lokasinya strategis, tersedianya prasarana dan sarana transportasi.Sesuai dengan keadaan itu pola persebaran objek wisata sebagai tempat yang sentral yang memiliki daya tarik wistawan yang paling pokok, dapat melayani kebutuhan wisatawan dan mempengaruhi atau melayani wisatawan di hotel melati. Kondisi yang demikian didukung kedua pola persebaran tersebut memiliki lokasi yang strategis, adanya ketersediaan prasarana dan sarana transportasi yang dalam kenyataannya jumlah wisatawan meningkat dan telah mengalami perkembangan dalam melayani kebutuhan pengunjung di hotel melatiyang pada gilirannya dapat mendukung perkembangan pariwisata terutama perkembangan pelayanan fasilitas sekunder pariwisata di Kota Medan.

Keadaan tersebut tidak jauh berbeda dengan yang dikatakan Cristaller (dalam Setiawan, 2003) yakni bahwa cara baik untuk menyediakan pelayanan berdasarkan aspek keruangan kepada penduduk adalah dengan menerapkan aktivitas pada hirarki permukiman yang luasnya meningkat dan lokasinya ada pada simpul-simpul jaingan heksagonal. Oleh karena itu lokasi kegiatan yang melayani kebutuhan penduduk itu harus ada pada lokasi yang sentral. Sehingga situasi lalulintas yang optimum memiliki pengaruh setengah dari bagian tetangga disekitarnya yang bebentuk heksagonal selain mempengaruhi wilyah itu sendiri.kondisi ini berlaku juga untuk pola persebaran objek wisata dan pola persebaran hotel melati di Kota Medan.

\section{KESIMPULAN DAN SARAN \\ Kesimpulan}

Berdasarkan Pembahasan, maka dapat ditarik beberapa kesimpulan sebagai berikut :

1. Pola persebaran objek wisata di Kota Medan tergolong pola persebaran objek wisata yang mengelompok hal ini disebabkan objek wisata menarik bagi wisatawan dan bernilai untuk dikunjungi. Keadaan ini didukung oleh letaknya strategis karena dekat dengan permukiman penduduk, tersedianya prasarana jalan aspal dalam kondisi baik dan sarana angkutan darat, kereta api, bandara polonia termasuk angkutan laut melalui Pelabuhan Belawan.

2. Pola persebaran hotel berbintang di Kota Medan termasuk pola persebaran hotel yang mengelompok. Hal ini disebabkan jarak hotel ke objek wisata relatif dekat sehingga dapat melayani kebutuhan wisatawan yang beranekaragam di hotel berbintang satu sampai hotel berbintang lima yang pada akhirnya dapat mendukung perkembangan pariwisata khususnya perkembangan pelayanan fasilitas sekunder pariwisata di Kota Medan.

3. Pola Persebaran fasilitas hotel melati di Kota Medan tergolong pola persebaran hotel yang mengelompok. Keadaan ini terutama disebabkan pola persebaran yang semakin efektif atau semakin mengelompok sehingga semakin terlayani kebutuhan wisatawan di hotel melati yang pada gilirannya dapat mendukung perkembangan pariwisata termasuk perkembangan pelayanan fasilitas sekunder pariwisata di Kota Medan.

4. Pola persebaran objek wisata memiliki kesesuaian dengan pola persebaran fasilitas hotel berbintang. Kesesuaian kedua pola ini mencakup dalam pola persebaran, letaknya strategis dan ketersediaan prasarana termasuk sarana transportasi dalam melayani kebutuhan wisatawan.

5. Pola persebaran objek wisata memiliki kesesuaian dengan pola persebaran hotel melati. Kesesuaian kedua pola tersebut meliputi dalam hal pola persebaran, letaknya strategis, tersedianya prasarana dan sarana perhubungan. 
Saran

Sesuai dengan uraian kesimpulan, maka diambil beberapa saran antara lain :

1. Pola persebaran objek wisata di Kota Medan menarik bagi wisatawan dan telah dapat melayani kebutuhan wisatawan tersebut, namun masih memiliki kelemahan. Oleh karena itu sudah selayaknya Dinas Kebudayaan dan Pariwisata Kota Medan melalui pihak pengelola objek wisata agar membenahi dan meningkatkan pelayanan kebutuhan wisatawan pada masa yang akan datang.

2. Pola persebaran hotel berbintang pada umumnya sudah dapat melayani kebutuhan wisatawan yang beranekaragam, akan tetapi hasilnya belum optimal. Sehubungan dengan itu sudah sewajarnya pihak pengelola hotel berbintang dapat meningkatkan pelayanan sesuai dengan keinginan dan kebutuhan para wisatawan dengan harapan dapat meningkatkan jumlah wisatawan.

3. Pola persebaran hotel melati telah dapat melayani kebutuhan pengunjung, namun hasilnya belum sesuai dengan yang diharapkan. Berkaitan dengan itu sudah sebaiknya pihak pengelola hotel melati dapat mebenahi dan meningkatkan pelayanan kebutuhan wisatawan agar jumlah wisatawan semakin meningkat pada tahun selanjutnya.

4. Pola persebaran objek wisata memiliki kesesuaian dengan pola persebaran hotel berbintang dalam melayani kebutuhan wisatawan, akan tetapi belum optimal. Oleh karena itu sudah sepantasnya Dinas Kebudayaan dan Pariwisata Kota Medan melalui pengelola objek wisata agar dapat meningkatkan kerjasama dengan pihak pengelola hotel berbintang dalam menangani pelayanan untuk memenuhi kebutuhan wisatawan yang beranekaragam di tempat hotel berbintang.
5. Pola persebaran objek wisata memiliki kesesuaian dengan pola persebaran hotel melati dalam melayani kebutuhan wisatawan, namun masih ada kelemahan. Sehubungan dengan itu, sudah selayaknya Dinas Kebudayaan dan Pariwisata Kota Medan melalui pengelola objek wisata agar dapat meningkatkan kerjasama dengan pihak pengelola hotel melati dalam menangani pelayanan untuk memenuhi kebutuhan wisatawan di tempat hotel melati.

\section{DAFTAR PUSTAKA}

Anonym.http://wikipedia.org. diakses 2009/09/26.

Bintarto, R dan Surastopo Hadisumarno. 1991. Metode Analisa Geografi. Jakarta: LP3ES.

BPS. 2015. Badan Pusat Statistik. Medan: BPS.

BPS. 2016. Badan Pusat Statistik. Medan: BPS.

Burton, R. 1995. Travel Geography. London: Pitman Publishing.

Damatra, Andipa. 2013. Perubahan Fasilitas Pariwisata Non Primer Tahun 2005 dan 2012 Di Kawasan Wisata Pangandaran.Skripsi. Jakarta: Jurusan Geografi FMIPA UI.

Dinas Pariwisata dan Kebudayaan Kota Medan. 2016. Medan: Dinas Pariwisata dan Kebudayaan.

Kemenristek. 2013. Modul 3 Geo Spasial. Bandung: Kementerian Riset dan Teknologi.

Kurniawan, Bayu. 2008. Pola Ruang Wisata Pantai Pulau Untung Jawa Kepulauan Seribu. Skripsi. Jakarta: Jurusan Geografi FMIPA UI.

Lumbantoruan, W. (2010). Studi Perkembangan Kota Medan 
Menggunakan Data Penginderaan Jauh Dan SIG. JURNAL GEOGRAFI, 2(2), 93-106.

Mardanti, Lokita. 2011. Perkembangan Fasilitas Wisata Sekunder Di Kabupaten Samosir Tahun 2004 Dan 2010.Skripsi. Jakarta: Jurusan Geografi FMIPA UI.

Ngafenan, Mohammad. 1994. Kamus Pariwisata. Semarang: Dahara Prize.

Pendit, Nyoman S. 1994. Ilmu Pariwisata : Sebuah Pengantar Perdana. Jakarta: Pradnya Paramita.

Pinem, M., \& Natalia, I. (2017). Persebaran dan Potensi Objek Wisata di Kota Medan. JURNAL GEOGRAFI, 1(1), 5764.

Prajogo, M. 1976. Pengantar Pariwisata Indonesia.Jakarta: UI-Press.

Sari, Putri Puspita. 2013. Analisis Pengembangan Pariwisata Kota Medan.Skripsi. Jakarta: Jurusan Geografi FIS UNIMED Medan.
Setiawan, Edi dan Harmanto, Gatot.2003.Geografi. Bandung: GrafindoMedia Pratama.

Spillane, James. 1985. Pariwisata Indonesia. Jakarta: Gramedia.

Suhardjo,A.J. 1996. Konsep-Konsep Dasar Dalam Geografi. Yogyakarta: Program Pascasarjana Fakultas Geografi UGM.

Suwantoro, Gamal. 2004. Dasar-Dasar Pariwisata. Yogyakarta: Andi.

Wahab,Saleh. $1996 . \quad$ Manajemen Kepariwisataan. Jakarta: Pradya Paramita

Wenny,Febriani. 2010. PolaRuang Kegiatan Ekonomi Masyarakat di Kawasan Wisata Cipanas, Kabupaten Garut.Skripsi. Jakarta: Jurusan Geografi FMIPA UI.

Yoeti, Oka A. 1982. Pengantar Ilmu Pariwisata. Bandung: Angkasa. 